\title{
Different Methods for Overcoming Integumental Dormancy during in vitro Germination of Red Araza Seeds
}

\author{
Cassio G. Freire ${ }^{1}$, João P. P. Gardin², César M. Baratto ${ }^{2} \&$ Renato L. Vieira ${ }^{3}$ \\ ${ }^{1}$ University Alto Vale do Rio do Peixe, St. Victor Baptista Adami, Center, Caçador, SC, Brazil \\ ${ }^{2}$ University of West of Santa Catarina, Unoesc, Videira, SC, Brazil \\ ${ }^{3}$ Agricultural Research and Rural Extension Company of Santa Catarina, Epagri, Experimental Station of \\ Caçador, SC, Brazil \\ Correspondence: Cassio G. Freire, University Alto Vale do Rio do Peixe, 800, St. Victor Baptista Adami, Center, \\ Caçador, Santa Catarina, Zip Code: 89500-000, Brazil. Tel: 55-49-9132-9590. Email: \\ cassio.geremia@uniarp.edu.br
}

Received: October 21, 2016

Accepted: November 21, 2016

Online Published: December 15, 2016

doi:10.5539/jas.v9n1p174

URL: http://dx.doi.org/10.5539/jas.v9n1p174

The research is financed by UNIEDU Postgraduate Program of the State of Santa Catarina, Unoesc, \& Epagri.

\begin{abstract}
Red Araza, or Red Strawberry Guava (Psidium cattleianum Sabine) is a native Brazilian Atlantic Forest species of the Myrtaceae family, whose seeds exhibit integumental dormancy. Due to its importance to different industries worldwide, recent research efforts are seeking to expand this species' micropropagation processes using in vitro seedling germination, especially since in vitro micropropagation of adult plant material has, so far, been limited. This research effort evaluated different methods of overcoming integumental dormancy during in vitro germination of the Red Araza, so as to allow future micropropagation of the species. The seeds' emergence and vigor were evaluated based on mechanical and acid scarification, using different substrates and immersions in solutions with different levels of gibberellic acid $\left(\mathrm{GA}_{3}\right)$, and on the influence of the pre-immersion of seeds in water and sulfuric acid. The mechanical and acid scarification of the seeds, combined or separate, resulted in higher in vitro germination percentages and a higher germination rate index (GRI). Pre-immersion in distilled water ( 20 hours) also proved to be efficient for the germination of the Red Araza seed, with $76.2 \%$ of the seeds germinating and a higher speed of emergence $(\mathrm{GRI}=0.18)$. When compared to a Murashige and Skoog (MS-zero) medium, sowing in a hydrophilic cotton substrate showed greater emergence and vigor, with approximately $70 \%$ of the seeds germinating. Treating the seeds by pre-immersing them in $\mathrm{GA}_{3}$ turned out to be unnecessary. The methods used for overcoming integumental dormancy during in vitro germination of Red Araza seeds proved to be efficient, and could be used to develop micropropagation protocols of seminal origin for this species.
\end{abstract}

Keywords: acid scarification, Araçá, gibberelic acid, mechanical scarification, myrtaceans, red strawberry guava, tegumentar dormancy

\section{Introduction}

A species of the Myrtaceae family, Red Araza, or, hereinafter, Red Strawberry Guava (Psidium cattleianum Sabine) is native to the Brazilian Atlantic Forest, but also found in different tropical and subtropical ecosystems (Tng et al., 2015). It's an arboreal species that produces a fleshy fruit with peculiar taste, possessing a rich chemical composition (Galho, Lopes, Bacarin, \& Limac, 2007), a large variety of bioactive compounds, such as phenolics and carotenoids (Silva, Rodrigues, Mercadante, \& De Rosso, 2014), as well as essential oils and other volatile compounds of pharmacological interest (Marin et al., 2008). Previous studies have already determined that aqueous and ketone extracts from the Red Strawberry Guava generate various antioxidant activities, have an anti-proliferative effect on human cancer cells, and acts as an antimicrobial agent against Salmonella enteritidis (Medina et al., 2011).

Due to its heightened importance to the agro-industrial and pharmacological fields, many studies have been done with the intent to broaden the knowledge base concerning this species' variability and genetic 
selection, its use in biotechnological processes, details regarding its ecological management and the establishment of commercial orchards/plant husbandries (Kinupp, 2011). Studies that focus on the in vitro propagation of Red Strawberry Guava can promote important mechanisms for the sustainable exploitation of this species; mechanisms that, up until now, have been rather scarce (Pasqual, Chagas, Soares, \& Rodrigues, 2012).

To date, tests for the in vitro introduction and multiplication of these Myrtaceae using herbaceous branches have proved ineffective, mainly due to the high percentage of in vitro phenol oxidation and microbial contamination (Rodríguez, 2013; Freire, Oliveira, \& Vieira, 2014). Consequently, protocols developed from in vitro germinated seedlings are being actively investigated as a feasible alternative to species micropropagation, especially considering that they have contributed to producing healthy explants and allowed for the continuity of in vitro propagation processes.

Red Strawberry Guava seeds, however, are known to show integumental dormancy and other studies about its in vitro germination can be developed under different conditions so as to optimize and homogenize seedling emergence (Da Silva, Perez, \& De Paula, 2011). With that in mind, this study set out to optimize the in vitro germination of red Strawberry Guava (Psidium cattleianum Sabine, Myrtaceae), using different methods to overcome its inherent integumental dormancy, in order to obtain healthy seedlings that can later contribute to the development of micropropagation processes.

\section{Materials and Methods}

\subsection{Obtaining the Seeds}

The seeds were obtained in 2014 from ripe fruits collected from 9-year-old Red Strawberry Guava trees $\left(26^{\circ} 49^{\prime} 06^{\prime \prime} \mathrm{S}-50^{\circ} 59^{\prime} 29^{\prime \prime} \mathrm{W}\right.$ and $\left.26^{\circ} 46^{\prime} 15^{\prime \prime} \mathrm{S}-51^{\circ} 02^{\prime} 09^{\prime \prime} \mathrm{W}\right)$ located in Caçador, a city in the southern state of Santa Catarina, in Brazil. The seeds were completely extracted from the pulp, in running water, placed on paper towels, at room temperature and without direct sunlight, and kept under these conditions for five days, until it was time to start the experiments.

\subsection{Experimental Conditions}

The experiments were performed according to ISTA rules (ISTA, 1999), in the state of Santa Catarina, Brazil, at EPAGRI's (Portuguese acronym for State of Santa Catarina Agricultural, Livestock, and Rural Extension Research Company) Plant Tissue Culture Laboratory. The experiments were set up in a growth chamber where the flasks were then exposed to a 16-hour photoperiod sourced by cold, white fluorescent lamps, with intensity set at $75 \mu \mathrm{mol} \mathrm{m} \mathrm{s}^{-2} \mathrm{~s}^{-1}$, and a temperature of $25 \pm 2{ }^{\circ} \mathrm{C}$. The following two types of substrate mediums were used: a cotton medium (2.05 grams flask $^{-1}$ of hydrophilic cotton moistened with 20 $\mathrm{mL}$ of distilled water and autoclaved for 25 minutes, at $121^{\circ} \mathrm{C}$ and $1.2 \mathrm{~atm}$ ) and a complete MS-zero medium (25 mL flask ${ }^{-1}$ ) (Murashige \& Skoog, 1962). The substrates were placed in closed flasks with the following dimensions and capacity: height $=95 \mathrm{~mm}$, diameter $=65 \mathrm{~mm}$, and a capacity of $230 \mathrm{~mL}$. Operating within a laminar flow hood, a standard asepsis method was used on the seeds by immersing them for one minute in $70 \% \mathrm{v} / \mathrm{v}$ ethanol, followed by a 15 minutes immersion in a $\mathrm{NaClO}$ solution with $1.5 \%$ an active principle and containing Tween $20 ®$ detergent $\left(10\right.$ drops $\left.\mathrm{L}^{-1}\right)$, and washing them three times with sterile distilled water. The seeds that exhibited root protrusions equal to or greater than $2.0 \mathrm{~mm}$ were considered to have been germinated (Borghetti \& Ferreira, 2004). Two were the factors assessed during the experiments: the germination rate index (GRI) and the germination percentage. According to Maguire (1962), the GRI was calculated using Equation (1) based on every other day assessments. The germination percentage was calculated after periods of time stipulated for each experiment.

$$
\mathrm{GRI}=(\mathrm{G} 1 / \mathrm{N} 1)+(\mathrm{G} 2 / \mathrm{N} 2)+(\mathrm{G} 3 / \mathrm{N} 3)+(\mathrm{Gn} / \mathrm{Nn})
$$

Where,

$\mathrm{G} 1, \mathrm{G} 2, \mathrm{G} 3, \ldots \mathrm{Gn}=$ number of seeds germinated in the first, second, third and thru to the last count;

$\mathrm{N} 1, \mathrm{~N} 2, \mathrm{~N} 3, \ldots \mathrm{Nn}=$ number of days from the time of sowing to the first, second, third and thru to the last count.

Every time the terms standard asepsis method, cotton substrate and MS-zero substrate are mentioned in this paper, they shall be consistent with the descriptions contained in this section.

\subsection{Determining Moisture Level}

The seeds' moisture level was determined according to Brasil (2009); in other words, in three groups of 50 seeds, each using the oven-dried method, at $105 \pm 3{ }^{\circ} \mathrm{C}$, for a period of 24 hours. 


\subsection{Mechanical and Acid Scarification of the Integument}

Eight treatments were arranged in a $2 \times 4$ factorial design, containing two levels of mechanical scarification (sanded and unsanded seeds), four levels of acid scarification (immersion in a $9 \mathrm{~mol} \mathrm{~L}^{-1} \mathrm{H}_{2} \mathrm{SO}_{4}$ solution for zero, five, ten, and 20 minutes) and five replications, each containing 10 seeds. For the mechanical scarification, an autoclaved metal sandpaper was used, scouring both sides of the seeds' integument adjacent to the micropyle. Subsequently, the acid scarification was performed by immersing the different seed samples in an acid solution under constant agitation. The seeds were then drained of the acid and subjected to a standard asepsis method, with cotton as the substrate. The GRI and the germination percentage were assessed, with the latter being assessed after 62 days in vitro.

\subsection{Substrate and Gibberellic Acid $\left(G A_{3}\right)$ Concentrations Tests}

Using a laminar flow hood, the seeds were immersed in distilled water for 20 hours, and in a $9 \mathrm{~mol} \mathrm{~L}^{-1}$ $\mathrm{H}_{2} \mathrm{SO}_{4}$ solution for ten minutes, washed in sterile distilled water, and then subjected to a standard asepsis method. The treatments were arranged in a $2 \times 4$ factorial design, with two substrates (cotton and MS-zero medium), and four concentrations of $\mathrm{GA}_{3}$ (Sigma $\left(\right.$ ) $\left(0 \mathrm{mg} \mathrm{L}^{-1}, 250 \mathrm{mg} \mathrm{L}^{-1}, 500 \mathrm{mg} \mathrm{L}^{-1}\right.$, and $\left.1000 \mathrm{mg} \mathrm{L}^{-1}\right)$. Six replications, each containing five seeds, were performed per treatment so the GRI and germination percentage could be assessed (after 80 days).

\subsection{Influence of Water Immersion and Acid Scarification}

Four different treatments were tested (T1, T2, T3, and T4), with seven replications, each containing six seeds, as described in Table 1.

Cotton was used as the substrate, and the GRI and germination percentage were assessed (70 days after sowing).

Table 1. Different treatments for the in vitro germination of Red Strawberry Guava seeds

\begin{tabular}{ll}
\hline Treatments & Description \\
\hline T1 & Control - only "Standard Asepsis Method"a \\
T2 & "Water Immersion"b associated with "Standard Asepsis Method" \\
T3 & "Water Immersion" + "Acid Scarification"c and "Standard Asepsis Method" \\
T4 & "Water Immersion"b associated with "Reduced Asepsis"d \\
\hline
\end{tabular}

Note. ${ }^{\mathrm{a}}$ - One minute in $70 \% \mathrm{v} / \mathrm{v}$ ethanol, followed by 15 minutes in a $1.5 \% \mathrm{NaClO}$ solution, with an active principal containing 10 drops $\mathrm{L}^{-1}$ of Tween $20 \AA$ detergent. ${ }^{\mathrm{b}}$ - Immersion for 20 hours in distilled water. ${ }^{\mathrm{c}}{ }_{-}$ Immersion for 10 minutes in a $9 \mathrm{~mol} \mathrm{~L}^{-1} \mathrm{H}_{2} \mathrm{SO}_{4}$ solution. ${ }^{\mathrm{d}}$ - Same as the standard aseptic method, but with immersion time reduced to 3 minutes in $\mathrm{NaClO}$.

\subsection{Statistics and Data Analysis}

All tests were performed in a randomized design. The results were submitted to the Shapiro-Wilk normality test $(\mathrm{p}<0.05)$ and for analysis of variance (ANOVA), and, using the Scott-Knott test $(\mathrm{p}<0.05)$, their group means were later separated into qualitative variables and regression studies for quantitative variables. When outside the expected normality, the data was transformed into $\sqrt{(\mathrm{x}+0.1)}$.

\section{Results}

Under the experimental conditions described, the average moisture percentage for the Red Strawberry Guava seeds was stipulated at $9.29 \% \pm 0.036 \%$.

\subsection{Mechanical and Acid Scarification of the Integument}

By itself, mechanical scarification, achieved by sanding or not sanding the seed integument, did not significantly change the seeds' germination percentages $(\mathrm{p}=0.8783)$, resulting in average values of $43.0 \%$ and $43.5 \%$, respectively (see Figure 1$)$. However, acid scarification $(\mathrm{p}<0.0001)$ by itself and the interaction of both acid and mechanical scarification $(\mathrm{p}=0.0013)$ did significantly change in vitro germination percentages (see Figure 1). As immersion times in a $9 \mathrm{~mol} \mathrm{~L}^{-1} \mathrm{H}_{2} \mathrm{SO}_{4}$ solution increased, mechanically scarified seeds yielded positive quadratic germination increments, while the non-scarified seeds showed positive linear germination increments. Using regression analysis (see Figure 1), optimum immersion times 
for acid scarification were determined to be 20 minutes for unsanded seeds and 15 minutes for sanded seeds.

As was the case with germination percentages, only acid scarification $(\mathrm{p}<0.0001)$ by itself and the interaction of both acid and mechanical scarification $(\mathrm{p}=0.0013)$ yielded significant changes in germination rate indexes (GRIs) (see Figure 1). For seeds that were not mechanically scarified, results showed that germination vigor was highest when the acid scarification immersion time in a $9 \mathrm{~mol} \mathrm{~L}^{-1} \mathrm{H}_{2} \mathrm{SO}_{4}$ solution was 20 minutes. GRIs for mechanically scarified seeds, on the other hand, did not differ $(\mathrm{p}<0.05)$ for immersion times of five, ten and 20 minutes, which indicates that, under these conditions, a five-minute immersion is enough to obtain the highest GRI value.

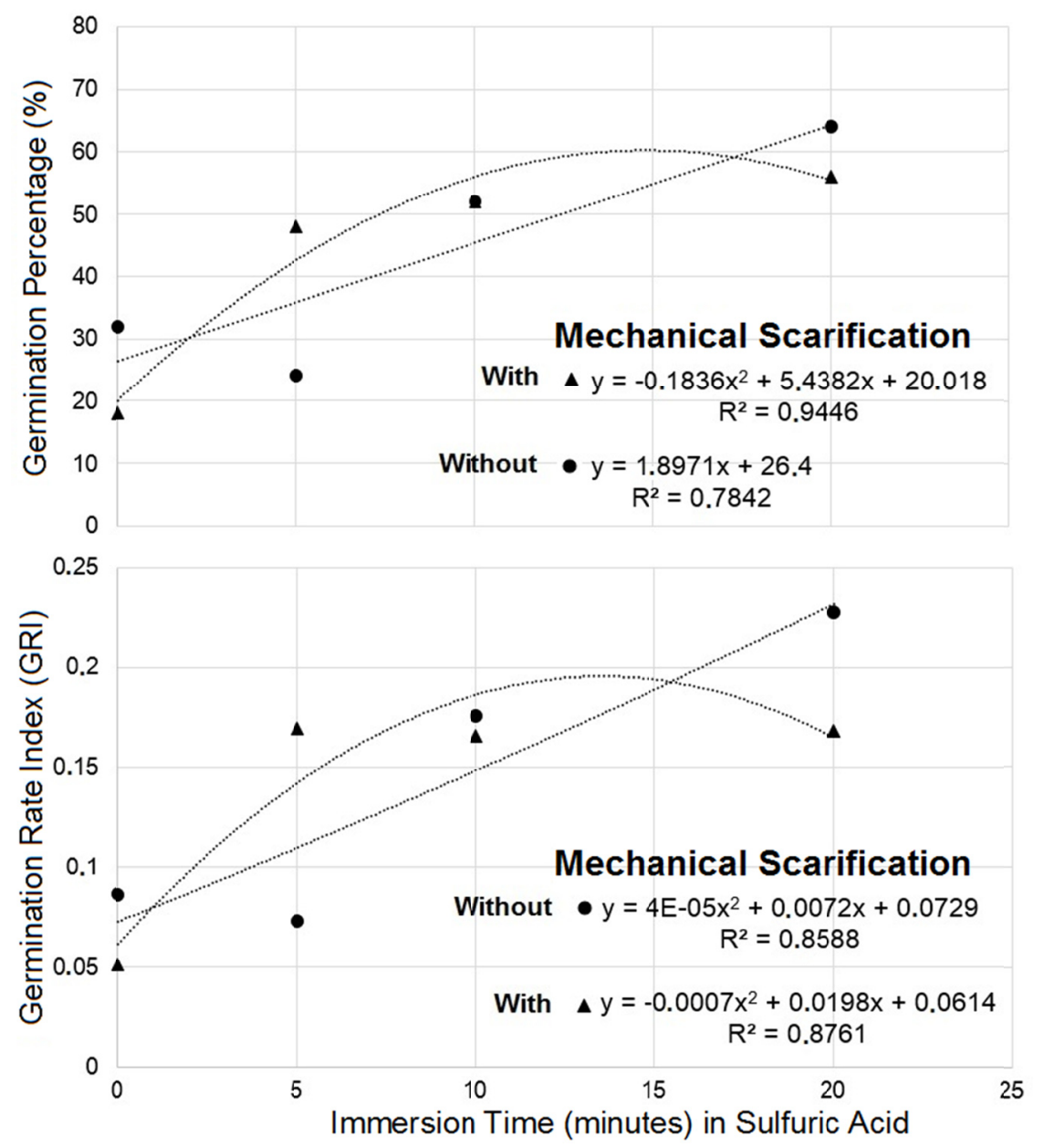

Figure 1. Germination percentages and germination rate index (GRI) for Red Strawberry Guava seeds (Psidium cattleianum) submitted or not to mechanical scarification (using sandpaper), and acid scarification with different immersion times in a $9 \mathrm{~mol} \mathrm{~L}^{-1} \mathrm{H}_{2} \mathrm{SO}_{4}$ solution, 62 days after in vitro sowing $(\mathrm{p}<0.05)$

\subsection{Substrate and Gibberellic Acid $\left(G A_{3}\right)$ Concentrations Tests}

Based on the data shown in Figure 2, one can see that the in vitro germination percentages of seeds placed on hydrophilic cotton were significantly higher $(\mathrm{p}<0.05)$ than for those placed in an MS-zero medium, with averages of $70.14 \%$ and $15.28 \%$, respectively. In spite of this, one can also see that both substrates exhibited very similar behavior. As $\mathrm{GA}_{3}$ concentrations increased, polynomial regressions indicated a reduction in germination percentage when the concentration increased above $100 \mathrm{mg} \mathrm{L}^{-1}$, increasing again as it went above $700 \mathrm{mg} \mathrm{L}^{-1}$ (see Figure 2). Also note that, of the four concentrations used in the experiment, the $0 \mathrm{mg} \mathrm{L}^{-1}, 250 \mathrm{mg} \mathrm{L}^{-1}$, and $1000 \mathrm{mg} \mathrm{L}^{-1}$ did not differ between them and provided higher germination percentages than the $500 \mathrm{mg} \mathrm{L}^{-1}$ concentration $(\mathrm{p}<0.05)$, regardless of the substrate used (see Figure 2). 
Pertaining to GRIs, after 94 days in vitro, significant effects $(p<0.0001)$ were detected only with regards to the type of substrate used, showing no GRI variations for the different concentrations of $\mathrm{GA}_{3}$ used ( $\mathrm{p}=$ $0.0690)$ nor for the interaction between the two factors $(\mathrm{p}=0.9045)$. Just like for the germination percentages (see Figure 2), the GRI obtained was higher for the cotton medium (on average, 7.32 times higher $)(\mathrm{p}<0.0001)$ than for the MS-zero medium.

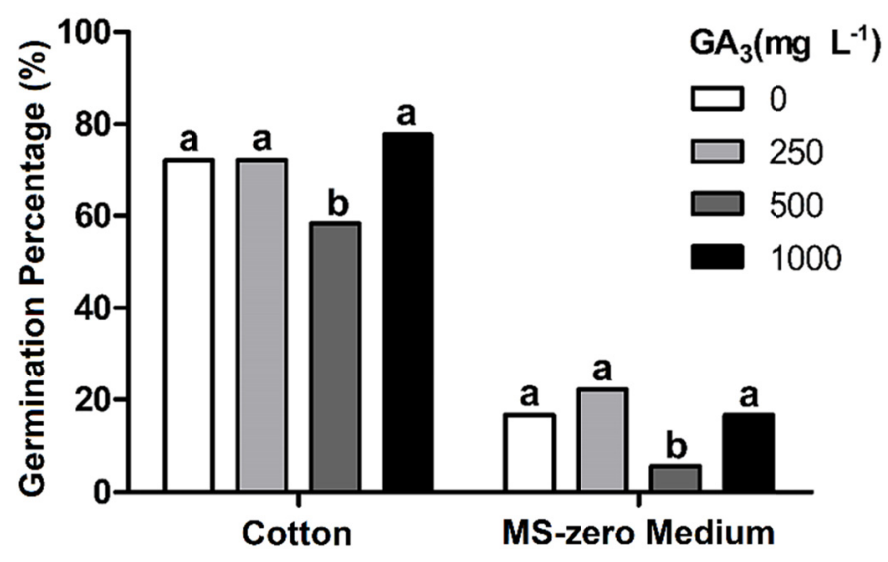

Figure 2. Germination percentages for Red Strawberry Guava seeds (Psidium cattleianum) submitted to different concentrations of $\mathrm{GA}_{3}$ on a moistened hydrophilic cotton substrate and a solidified MS-zero medium $\left(6 \mathrm{~g} \mathrm{~L}^{-1}\right.$ agar), 94 days after in vitro sowing

Note. Original values shown; for statistical analysis, values were transformed into $\sqrt{(\mathrm{x}+0.1)},(\mathrm{p}<0.05)$.

\subsection{Influence of Water Immersion and Acid Scarification}

The experiment showed that germination percentages did not vary significantly $(p=0.0911)$ as a result of the different treatments. However, when compared to the control group (T1), there was a definite increase in the number of seeds germinated when they were immersed in distilled water (T2), with $76.19 \%$ of seeds being germinated (Table 2).

Table 2. Germination rate index (GRI) and germination percentages for Red Strawberry Guava seeds (Psidium cattleianum) submitted to different treatments, 70 days after in vitro sowing

\begin{tabular}{lll}
\hline Treatments & GRI & Germination (\%) \\
\hline T1 & $0.10^{\mathrm{b}}$ & $52.38^{\mathrm{ns}}$ \\
T2 & $0.18^{\mathrm{a}}$ & 76.19 \\
T3 & $0.08^{\mathrm{b}}$ & 52.38 \\
T4 & $0.14^{\mathrm{a}}$ & 69.05 \\
\hline Variation coefficient $(\%)$ & 37.88 & 32.79 \\
\hline
\end{tabular}

Note. Within a column, the means with the same superscript letter do not differ statistically from the Scott-Knott test at $5 \% .{ }^{\mathrm{ns}}=$ not significant.

In terms of GRIs, the treatments yielded significant effects $(\mathrm{p}=0.0062)$, with treatments T2 and T4 showing greater seed vigor (Table 2). For Treatment 2 , the first germinated seed was observed on the $12^{\text {th }}$ day; for Treatment 4, it happened on the $16^{\text {th }}$ day; and, for Treatment 3, it happened only on the $20^{\text {th }}$ day. These results indicate that a 20 -hour immersion in distilled water (done for treatments T2, T3 and T4) reduces the time needed for the onset of germination, except when associated with acid scarification of ten minutes in a $9 \mathrm{~mol} \mathrm{~L}^{-1} \mathrm{H}_{2} \mathrm{SO}_{4}$ solution (treatment T3). In Table 2, one can see that treatment $\mathrm{T} 2$ yielded a GRI almost twice that of the control group (T1). The table also shows that, when acid scarification was used (T3), the GRI decreases significantly (approximately 55\%) when compared to treatment T2. 


\section{Discussion}

The acid scarification of Red Strawberry Guava seeds with $\mathrm{H}_{2} \mathrm{SO}_{4}$ proved to be more effective in increasing in vitro germination percentages and GRIs than mechanical scarification (Figure 1). Da Silva (2009) had already tested different $\mathrm{H}_{2} \mathrm{SO}_{4}$ immersion times in ex vitro germination experiments with the same species and, as was the case in this study, he noticed a quadratic germination decreasing trend when the seeds were subjected to immersion times greater than 15 minutes.

It is well known that $P$. cattleianum seeds have an impermeable integument due to its rocklike consistency (testa petrea) (Cisneiro, Matos, Lemos, Reis, \& Queiroz, 2003), which is, in part, responsible for the seed's low imbibition rate and consequent integumental dormancy (Da Silva et al., 2011). That fact led to the reasoning that mechanical or acid scarification helps to 'injure' the seed's integument, making it easier for water and gases to enter the embryo, which, in turn, favors its germination (Bertalot \& Nakagawa, 1998). Using that reasoning, this experiment found that increasing immersion times in a $9 \mathrm{~mol} \mathrm{~L}^{-1} \mathrm{H}_{2} \mathrm{SO}_{4}$ solution contributed to reducing the time needed for germination of the seeds. However, when the seeds had already been sanded and were subjected to acid scarification for periods greater than 15 minutes, there was a reduction in their germination percentages and GRIs (Figure 1). This could be related to the possibility that the seed integument was previously deteriorated, in which case, the immersion in acid for periods longer than 15 minutes may have caused chemical or physiological damage to the embryo, resulting in a lower germination capacity.

C. C. Baskin and J. M. Baskin (2014) claim that acid scarification immersion times for seeds with integument dormancy should be carefully tested, since even periods slightly longer than the ideal time may damage the embryo and prevent it from germinating. Furthermore, these authors also say that the addition of concentrated acids may change the $\mathrm{pH}$ levels of the solutions surrounding the embryo and, because of the specific $\mathrm{pH}$ levels required for germination, it would interfere with the germination process.

With respect to the in vitro germination substrates, this research effort found that sowing seeds in cotton increased the rate of germination and the final number of germinated seeds when compared to the MS-zero medium solidified with agar. Passos, Tavarez, and Alves (2007) also used moistened hydrophilic cotton for the germination of Sabia (Mimosa caesalpiniifolia) seeds and obtained a higher germination percentage with this substrate than with any of the others that were tested. In this study, the difference in how in vitro germination was affected by the different substrates became evident during experiment evaluations. On the $56^{\text {th }}$ day after the in vitro sowing, approximately $40 \%$ of the seeds placed in the cotton substrate had already germinated, whereas none had germinated in the MS-zero medium.

Unlike what was observed in this study, other authors obtained good in vitro germination percentages for myrtaceans, using saline culture mediums such as MS-zero, LPm and WPM. Cid, Machado, Carvalheira and Brasileiro (1999), for example, obtained good germination percentages for the Eucalyptus spp. in an MS-zero medium; similar results were obtained for the Cagaita (Eugenia dysenterica), using the same medium and yielding almost 90\% germination (Martinotto et al., 2007). Rodríguez (2013) obtained a 68.00\% germination result for the Red Strawberry Guava (P. cattleianum) using an LPm medium (Von Arnold \& Erikson, 1981). Also, Souza, Fior, Souza and Schwarz (2011) achieved an average of $70 \%$ in vitro germination when placing Guabijuzeiro (Myrcianthes pungens) seeds in a WPM medium.

Several substrate factors may affect a seed's germination quality. Since water and oxygen are essential to many metabolic processes that occur during a developing embryo's germination (Taiz \& Zeiger, 2013), one of these factors is the substrate's ability to maintain good water availability and aeration for the seed (Popinigis, 1985).

According to Gulliver and Heydecker (1973), up to a certain limit, the more water available to the seeds, the greater the speed of imbibition and absorption, resulting in faster germination of the seeds. Carvalho and Nakagawa (2000) also claim that water is the most significant factor influencing the germination process, especially considering that the embryo's development and growth depend on water imbibition by the seed and its subsequent absorption by the tissues, mechanisms that enhance breathing and other metabolic activities necessary to achieve seedling emergence and root protrusions.

The positive influence of high water availability in the substrate had already been established for the germination of different species, such as the white spruce (Picea glauca [Moench.] Voss.) (Downie et al., 1998), the Mesua ferrea (Joshi, Phartyal, Khan, \& Arunkumar, 2015), and also myrtaceans, such as the Guavira [Campomanesia adamantium (Cambess.) O. Berg.] (Dresch, Scalon, \& Kodama, 2011), the Brazilian Strawberry Guava (Psidium guineense Swartz) (Gonçalves et al., 2009) and the Uvaia (Eugenia pyriformis) (Scalon \& Jeromine, 2013). 
However, the high salt concentration of germination substrates and the solidification of the same using agar, for example, have been reported as negative factors to the seedling emergence process (Grattapaglia \& Machado, 1998). The solidification of the substrate increases the colloidal state of the same (Stoltz, 1971) and, as well as saline ions, increase the effectiveness of intermolecular interactions with water, which increases the osmotic pressure of the medium where the seeds are inserted (Doneen \& MacGilliwray, 1943). These factors increase the retention of water by the substrate, reducing the water absorption/imbibition by the seed, and directly affecting their physiological responses (Carvalho \& Nakagawa, 2000).

Accordingly, in this study, the difference in the availability of water between the cotton and the MS-zero mediums is believed to have contributed to the better germination percentages observed in the moistened cotton substrate (Figure 2).

This study also indicated that different concentrations of gibberellic acid $\left(\mathrm{GA}_{3}\right)$, in which the Red Strawberry Guava seeds were immersed, were not efficient enough to promote an increase in germination percentage, when compared to the control group. It's possible that this lack of efficiency occurred because the $\mathrm{GA}_{3}$ didn't properly stimulate the supply of nutrients to the embryo, or didn't contribute to the seed's production of endogenous gibberellins, a plant hormone that plays an essential role in the germination process. Other research efforts for the same species showed conflicting results regarding the effects of $\mathrm{GA}_{3}$ solutions on germination. Rodríguez (2013), for example, not only noted that there was no significant difference in germination when using $\mathrm{GA}_{3}$ concentrations of $0 \mathrm{mg} \mathrm{L}^{-1}, 10 \mathrm{mg} \mathrm{L}^{-1}, 20 \mathrm{mg} \mathrm{L}^{-1}$ and $50 \mathrm{mg} \mathrm{L}^{-1}$, but also found that the control group had a higher germination percentage. Tomaz et al. (2011), on the other hand, observed that, when previously immersed in a $500 \mathrm{mg} \mathrm{L}^{-1} \mathrm{GA}_{3}$ solution, a higher number of Red Strawberry Guava seeds successfully germinated. Interestingly, the concentration used by Tomaz et al. (2011) is the same that, in this study, resulted in lower germination percentages and vigor.

Exogenous applications of $\mathrm{GA}_{3}$ don't always have the expected effect on germination (Kermode, 2005) because it's dependent on other factors such as the endogenous concentration of abscisic acid and other inhibiting compounds present in the seed (Taiz \& Zeiger, 2013; Carvalho \& Nakagawa, 2000; Khan, 1971), or whether or not they are associated to beneficial microorganisms (Dalal \& Kulkarni, 2015). In addition, seed responses to exogenous applications of $\mathrm{GA}_{3}$ are quite specific, varying among different species of the same genus, or even within the same species (Kumar et al., 2012). As an example, for the genus Psidium, immersion in a $\mathrm{GA}_{3}$ solution promoted a significant increase in germination percentages of $P$. guajava seeds, when compared to the control group, to the group submitted to acid scarification with $\mathrm{HCl}$ and $\mathrm{H}_{2} \mathrm{SO}_{4}$ treatments, and even to the group that got immersed in distilled water (Chandra \& Govind, 1990). In contrast, germination of $P$. guineense seeds was not stimulated by $\mathrm{GA}_{3}$ solution immersions, yielding lower germination percentages than both the control group and the group immersed in distilled water (Dresch, Scalon, Neves, \& Masetto, 2014).

In terms of GRIs, results obtained in this study indicated that pre-immersion of the Red Strawberry Guava seeds in water for a period of 20 hours (T2 in Table 2) increases their germinating vigor, with GRI values almost double that of the control group. Other research efforts also showed that pre-immersion in water decreases the time to the onset of germination in many other species, for instance, the Tamarindus indica (Azad, Nahar, \& Matin, 2015), the Acrocomia aculeata (Rodrigues Junior et al., 2013), and the Acacia origena (Aref, Atta, Shahrani \& Mohamed, 2011). Acid scarification after the period of pre-immersion in water (T3 in Table 2), however, significantly reduced both the GRI and the in vitro germination percentages. Such results may have been caused by acidity induced chemical and/or physiological damages to the embryo, which would decrease the seed's germination capacity. Similar results were attained by Tavares, Lucca Filho, and Kersten (1995) when they immersed Guava (Psidium guajava) seeds in a $\mathrm{H}_{2} \mathrm{SO}_{4}$ solution, yielding a significant reduction in GRI, when compared to the control group.

It is important to note that acid scarification of seeds may trigger oxidative processes and deregulate $\mathrm{pH}$ levels in the regions surrounding the embryo (C. C. Baskin \& J. M. Baskin, 2014). This, in turn, may have negatively interfered in the germination process of Red Strawberry Guava seeds, possibly reducing physiological responses that affect the embryo's development.

\section{Conclusion}

Results led to the determination that immersion of non-mechanically scarified Red Strawberry Guava seeds in a $9 \mathrm{~mol} \mathrm{~L}^{-1} \mathrm{H}_{2} \mathrm{SO}_{4}$ solution for 20 minutes yields higher GRIs and in vitro germination percentages. When the seeds are mechanically scarified, 5- and 15-minute immersions in a $9 \mathrm{~mol} \mathrm{~L}^{-1} \mathrm{H}_{2} \mathrm{SO}_{4}$ solution yielded better results for GRI and germination percentages, respectively. The experiments also revealed that pre-immersing the seeds in solutions of $\mathrm{GA}_{3}$, with concentrations ranging from $0 \mathrm{mg} \mathrm{L}^{-1}$ to $1000 \mathrm{mg} \mathrm{L}^{-1}$, was irrelevant. Also, 
sowing the seeds in a moistened hydrophilic cotton substrate is more efficient and promotes higher rates of emergence and vigor, when compared to a complete MS-zero medium. Furthermore, pre-imbibition of the Red Strawberry Guava in distilled water for 20 hours increases both the in vitro germination speed and percentages.

In conclusion, this research effort showed that optimization processes for the in vitro germination of Red Strawberry Guava seeds are efficient, and can be used to obtain healthy in vitro seedlings, making it possible to further develop micropropagation protocols of seminal origin for this species.

\section{References}

Aref, I. M., Atta, H. A. E., Shahrani, T. A., \& Mohamed, I. A. (2011). Effects of seed pretreatment and seed source on germination of five Acacia spp. African Journal of Biotechnology, 10(71), 15901-15910. https://doi.org/10.5897/AJB11.1763

Azad, M. S., Nahar, N., \& Matin, M. A. (2013). Effects of variation in seed sources and pre-sowing treatments on seed germination of Tamarindus indica: A multi-purpose tree species in Bangladesh. Forest Science and Practice, 15(2), 121-129. https://doi.org/10.1007/s11632-013-0211-0

Baskin, C. C., \& Baskin, J. M. (2014). Seeds: Ecology, biogeography and evolution of dormancy and germination (2nd ed., p. 1585). Academic Press.

Bertalot, M. J., \& Nakagawa, J. (1998). Superação da dormência em sementes de Leucaena diversifolia (Schlecht.), Revista Brasileira de Sementes, 20(1), 39-42. https://doi.org/10.17801/0101-3122/rbs.v20 n1p39-42

Borghetti, F., \& Ferreira, A. F. (2004). Interpretation of results germination. In A. G. Ferreira, \& F. Borghetti (Eds.), Germination: from basic to applied (pp. 209-222). Porto Alegre: Artmed.

Carvalho, N. M., \& Nakagawa, J. (2000). Sementes: ciência, tecnologia e produção (4th ed., p. 588). Jaboticabal: FUNEP.

Chandra, R., \& Govind, S. (1990). Gibberellic acid, thiourea, ethrel and acid treatments in relation to seed germination and seedling growth in guava (Psidium guajava L.). Progressive Horticulture, 22(1), 40-43.

Cid, L. P. B., Machado, A. C. M. G., Carvalheira, S. B. R., \& Brasileiro, A. C. M. (1999). Plant regeneration from seedling explants of Eucalyptus grandis $\times$ E. urophylla. Plant Cell, Tissue and Organ Culture, 56(1), 17-23. https://doi.org/10.1023/A:1006283816625

Cisneiro, R. A., Matos, V. P., Lemos, M. A., Reis, O. V., \& Queiroz, R. M. (2003). Qualidade fisiológica de sementes de araçazeiro durante o armazenamento. Revista Brasileira de Engenharia Agrícola e Ambiental, 7(3), 513-518. https://doi.org/10.1590/S1415-43662003000300018

Da Silva, A. (2009). Morfologia, conservação e ecofisiologia da germinação de sementes de Psidium cattleianum Sabine. Unpublished dissertation in partial fulfillment of the requirements for the degree of Master in Ecology and Natural Resources. Universidade Federal de São Carlos, UFSCar, SP.

Da Silva, A., Perez, S. C. J. G. A., \& De Paula, R. C. (2011). Qualidade fisiológica de sementes de Psidium cattleianum Sabine acondicionadas e armazenadas em diferentes condições. Revista Brasileira de Sementes, 33(2), 197-206. https://doi.org/10.1590/S0101-31222011000200001

Dalal, J., \& Kulkarni, N. (2015). Effect of endophytic treatments on plant growth performance and disease incidences in soybean (Glycine max (L.) Merril) Cultivar JS-335 against challenge inoculation with $R$. solani. American Journal of Agricultural and Biological Sciences, 10(2), 99-110. https://doi.org/10.3844/ ajabssp.2015.99.110

Downie, B., Coleman, J., Scheer, G., Wang, B. S. P., Jensen, M., \& Dhir, N. (1998). Alleviation of seed dormancy in white spruce (Picea glauca [Moench.] Voss.) is dependent on the degree of seed hydration. Seed Science and Technology, 26, 555-569.

Dresch, D. M., Scalon, S. P. Q., \& Kodama, F. M. (2011). Crescimento inicial de mudas de Campomanesia adamantium (Camb.) O. Berg em diferentes substratos e disponibilidades hídricas. In XIII Congresso Brasileiro de Fisiologia Vegetal-XIV Reunião Latino-Americana de Fisiologia Vegetal, 2011, Buzios. Livro resumo, Periodical Brazilian Journal of Plant Physiology, Londrina.

Dresch, D. M., Scalon, S. P. Q., Neves, E. M. S., \& Masetto, T. E. (2014). Effect of pre-treatments on seed germination and seedling growth in Psidium guineense Swartz. Agrociencia Uruguay, 18(2), 33-39. Retrieved April 1, 2016, from https://www.researchgate.net/publication/271325658_Effect_of_Pre-treatmen ts_on_Seed_Germination_and_Seedling_Growth_in_Psidium_guineense_Swartz 
Freire, C. G., Oliveira, L. P. de, \& Vieira, R. L. (2014). Tratamento fungicida e diferentes assepsias na introdução in vitro de araçazeiro-vermelho (Psidium cattleianum) (pp. 14-14). In X Simpósio Florestal Catarinense, 2014, Curitibanos/SC. Anais do X Simpósio Florestal Catarinense Florestas Produtivas, Cenários e Perspectivas.

Galho, A. S., Lopes, N. F., Bacarin, M. A., \& Limac, M. G. S. (2007). Chemical composition and growth respiration in Psidium cattleyanum Sabine fruits during the development cycle. Revista Brasileira de Fruticultura, 29(1), 61-66. https://doi.org/10.1590/S0100-29452007000100014

Gonçalves, C. A. R. L., Kodama, F. M., Dresch, D. M., Scalon, S. P. Q., \& Pereira, Z. V. (2009). Germinação de Araza (Psidium guineense Swartz) em diferentes substratos e regimes hídricos. XVI Congresso Brasileiro de Sementes, Qualidade: Desafio Permanente. Informativo ABRATES, 19(2), 237.

Grattapaglia, D., \& Machado, M. A. (1998). Micropropagação. In A. C. Torres, L. S. Caldas, \& J. A. Buso (Eds.), Tissue culture and genetic transformation of plants (Vol. 1, pp. 183-260). Brasília: SPI/Embrapa, CNPH.

Gulliver, R. L., \& Heydecker, W. (1973). Establishment of seedlings in a changeable environment. In W. Heydecker (Ed.), Seed Ecology (pp. 433-462). London, Butterworth.

ISTA. (1999). International rules for seed testing. Seed Science Technology, 27(Suppl.).

Joshi, G., Phartyal, S. S., Khan, M. R., \& Arunkumar, A. N. (2015). Recalcitrant morphological traits and intermediate storage behaviour in seeds of Mesua ferrea, a tropical evergreen species. Seed Science and Technology, 43, 121-126. https://doi.org/10.15258/sst.2015.43.1.13

Kermode, A. R. (2005). Role of abscisic acid in seed dormancy. Journal of Plant Growth Regulation, 24, 319-44. https://doi.org/10.1007/s00344-005-0110-2

Khan, A. A. (1971). Cytokinins: permissive role in seed germination. Science, 171, 853-859. https://doi.org/ 10.1126/science.171.3974.853

Kinupp, V. F. (2011). Native food species from southern Brazil. In L. Coradin, A. Siminski, \& A. Reis (Eds.), Native species of flora of current or potential economic value: Plans for the future (p. 934). South Brasília: MMA.

Kumar, R., Misra, K. K., Misra, D. S., \& Brijwal, M. (2012). Seed germination of fruit crops: A review. HortFlora Research Spectrum, 1(3), 199-207.

Maguire, J. D. (1962). Speed of germination aid in selection and evaluation for seedling emergence and vigor. Crop Science, 2(1), 176-177. https://doi.org/10.2135/cropsci1962.0011183X000200020033x

Marin, R., Apel, M. A., Limberger, R. P., Raseira, M. C. B., Pereira, J. F. M., Zuanazzi, J. A. S., \& Henriques, A. T. (2008). Volatile components and antioxidant activity from some myrtaceous fruits cultivated in southern Brasil. Latin American Journal of Pharmacy, 27(2), 172-177.

Martinotto, C., Paiva, R., Santos, B. R., Soares, F. P., Nogueira, R. C., \& Silva, A. A. N. (2007). Effect of scarification and light on in vitro seed germination of (Eugenia dysenterica DC.). Ciência e Agrotecnologia, 31(6), 1668-1671. https://doi.org/10.1590/S1413-70542007000600010

Medina, A. L., Haas, L. I. R., Chaves, F. C., Salvador, M., Zambiazi, R. C., Da Silva, W. P., ... Rombaldi, C. V. (2011). Araza (Psidium cattleianum Sabine) fruit extracts with antioxidant and antimicrobial activities and antiproliferative effect on human cancer cells. Food Chemistry, 128, 916-922. https://doi.org/10.1016/ j.foodchem.2011.03.119

Ministério da Agricultura, Pecuária e Abastecimento, Brasil. (2009). Regras para análise de sementes. [Rules for seed testing] (p. 399). Secretaria de Defesa Agropecuária. Brasília: Mapa/ACS.

Murashige, T., \& Skoog, F. (1962). A revised médium for rapid growth and bioassay with tobacco tissue cultures. Physiologia Plantarum, 15, 473-497. https://doi.org/10.1111/j.1399-3054.1962.tb08052.x

Pasqual, M., Chagas, E. A., Soares, J. D. R., \& Rodrigues, F. A. (2012). Tissue culture techniques for native Amazonian fruit trees. In A. Leva, \& L. M. R. Rinaldi (Eds.), Recent advances in plant in vitro culture (p. 220). Intech. https://doi.org/10.5772/52211

Passos, M. A., Tavares, K. M. P., \& Alves, A. R. (2007). Dormancy and development in "sabiá" (Mimosa caesalpiniifolia Benth.) seeds. Revista Brasileira de Ciências Agrárias, 2(1), 51-56.

Popinigis, F. (1985). Fisiologia da semente (2nd ed., p. 289). Brasília, DF: [s.n]. 
Rodrigues Junior, A. G., Oliveira, T. G. S., Souza, P. P., \& Ribeiro, L. M. (2013). Water uptake and pre-germination treatments in macaw palm (Acrocomia aculeata-Arecaceae) seeds. Journal of Seed Science, 35(1), 99-105. https://doi.org/10.1590/S2317-15372013000100014

Rodríguez, E. A. G. (2013). Contribuições à propagação de araçazeiro (Psidium cattleianum Sab.) e grumixameira (Eugenia brasiliensis Lam.). Unpublished dissertation in partial fulfillment of the requirements for the degree of Master in Plant Science with emphasis on horticulture. Universidade Federal do Rio Grande do Sul, Porto Alegre, RS.

Scalon, S. P. Q., \& Jeromine, T. S. (2013). Substrate and water levels on the germinative potential of seeds of uvaia. Revista Árvore, 37(1), 49-58. https://doi.org/10.1590/S0100-67622013000100006

Silva, N. A., Rodrigues, E., Mercadante, A. Z., \& De Rosso, V. V. (2014). Phenolic compounds and carotenoids from four fruits native from the Brazilian Atlantic Forest. Journal of Agricultural and Food Chemistry, 62, 5072-5084. https://doi.org/10.1021/jf501211p

Souza, L. S., Fior, C. S., Souza, P. V. D., \& Schwarz, S. F. (2011). Disinfestation of seeds and in vitro multiplication of guabijuzeiro from apical segments juveniles (Myrcianthes pungens O. Berg) D. Legrand. Revista Brasileira de Fruticultura, 33(3), 691-697. https://doi.org/10.1590/S0100-29452011005000081

Stoltz, L. P. (1971). Agar restriction of the growth of excised mature Iris embryos. Journal of the American Society for Horticultural Science, 96, 681-684.

Taiz, L., \& Zeiger, E. (2013). Plant Physiology (5th ed., p. 918). In A. M. D. Junior et al. (trad.), P. L. de Oliveira (rev. tecn.). Porto Alegre: Artmed.

Tavares, M. S. W., Lucca Filho, O. A., \& Kersten, E. (1995). Germination and vigor of guava seeds (Psidium guajava L.) submitted to different methods to supress dormancy. Ciência Rural, 25(1), 11-15. https://doi.org/10.1590/S0103-84781995000100003

Tng, D. Y. P., Goosem, M. W., Paz, C. P., Preece, N. D., Goosem, S., Fensham, R. J., \& Laurance, S. G. W. (2015). Characteristics of the Psidium cattleianum invasion of secondary rainforests. Austral Ecology.

Tomaz, Z. F. P., Galarça, S. P., Lima, C. S. M., Betemps, D. L., Gonçalves, M. A., \& Rufato, A. R. (2011). Tratamentos pré-germinativos em sementes de araçazeiro (Psidium cattleyanum Sabine L.). Revista Brasileira de Agrociência, Pelotas, 17(1-4), 60-65.

Von Arnold, S., \& Erikson, T. (1981). In vitro studies of adventitious roots formation in Pinus contorta. Canadian Journal of Botany, 59, 870-874. https://doi.org/10.1139/b81-121

\section{Copyrights}

Copyright for this article is retained by the author(s), with first publication rights granted to the journal.

This is an open-access article distributed under the terms and conditions of the Creative Commons Attribution license (http://creativecommons.org/licenses/by/4.0/). 